\section{SOCIETIES AND ACADE.MIES} LoNDoN.

Chemical Society, December 13, 1900.-Prof. Thorpe, President, in the chair. - Prof. H. A. Miers delivered the Ram melsberg Memorial Lecture. - December 20, I900, Prof. Thorpe, President, in the chair.-On the union of hydrogen and chlorine, by J. W. Mellor. The mixture of hydrogen and chlorine obtained by the electrolysis of hydrochloric acid always contain measurable quantities of oxygen. A slight contraction occurs on mixing gaseous chlorine and hydrogen chloride. - The nitration of the three tolueneazophenols, by J. T. Hewitt and J. H. Lind field. The three tolueneazophenols are nitrated by warm dilute nitric acid, and in each case the nitro-group enters the phenol ring in the ortho-position relatively to the hydroxyl group. The bromination of the ortho-oxyazo-compounds and its bearing on their constitution, by J. T. Hewitt and H. A. Phillips. Ortho oxyazo-compounds appear to react towards bromine as true oxyazo-compounds, and not as orthoquinone-hydrazones.-On the use of pyridine for molecular weight determinations by the ebullioscopic method, by W. R. Innes. Molecular weight de terminations show that pyridine does not favour the association of dissolved substances; its molecular rise in boiling point is 29.5 . The influence of the nethyl group on ring formation, by A. W. Gilbody and C. H. G. Sprankling. The authors have determined the stability of phenylsuccinimide and its alky derivatives in alcoholic solution. It is found that the stability of the succinimide ring is decreased by introducing methyl groups into the fatty ring, whilst Miolati has found that the in troduction of fatty groups into the aromatic ring increases the stability. - Experiments on the production of optically active compounds from inactive substances, by F. S. Kipping.-A lecture table experiment for the preparation of nitric oxide, by A. Senier. - The action of ethylene dibromide on xylidine and pseudocumidine, by A. Senier and W. Goodwin.-The action of phenylcarbimide on diphenyl-, dialphyl- and dinaphthyl-diamines, by A. Senier and W. Goodwin.--Note on the action of nitrous acid on $\beta$-nitroso- $\alpha$-naphthylamine, by $A$. Harden and J. Okell. On treating $\beta$-nitroso-a-naphthylamine in alcoholic solution with potassium nitrite and hydrochloric acid, a salt of the composition $\mathrm{C}_{10} \mathrm{H}_{6} \mathrm{O}_{12} \mathrm{~N}_{3} \mathrm{~K}$ is obtained; this and the corresponding sodium salt, when treated with stannous chloride and acid, yield a substance which is probably an imidazole of the following constitution--

$$
\mathrm{C}_{10} \mathrm{H}_{\mathrm{ti}} \backslash \underset{\mathrm{N}(\mathrm{OH})}{--\mathrm{N}} \backslash \mathrm{N}
$$

-1:2:4-Metaxylidine-6-sulphonic acid, by H. F. Armstrong and L P. Wilson. In accordance with the views previously published by Armstrong, it is found that although excess of fuming sulphuric acid converts $1: 2: 4$-metaxylidine into the 5-sulphonic acid, the 6-sulphonic acid is readily obtainable by heating the sulphate of the base. - The preparation of acetyl. chloraminobenzene and related compounds, by $\mathrm{F} . \mathrm{D}$. Chattaway and K. J. P. Orton.

Geological Society, December 19, 1900.-J. J. H. Teall, F.R.S., President, in the chair.-On the igneous rocks associated with the Cambrian beds of the Malvern Hills, by Prof. T. T. Groom. The Cambrian beds of the Southern Malverns are associated with a series of igneous rocks which have commonly been regarded as volcanic, but are probably all intrusive. They consist of a series of bosses, dykes, sills and small laccolites intruded into the Upper Cambrian Shales and into the Hollybush Sandstone. The dykes appear to be confined to the sandstones, the sills and laccolites chiefly to the shales, while the bosses are found in both. All the rocks have a local stamp, but are probably most nearly related to the camptonitic rocks of the Central English Midlands. Intrusion took place at a period not earlier than the Tremadoc, and probably not later than that of the May Hill Sandstone. - On the Upper Greensand and Chloritic Marl of Mere and Maiden Bradley in Wiltshire, by A. J. Jukes-Browne and John Scanes. The district dealt with is on the borders of Wiltshire and Somerset. The general succession is as follows, the numbers being given in feet :-Iower Chalk, with Chloritic Marl at the base, 200; sands with calcareous concretions, 3 to 8 ; sands with siliceous concretions (cherts), 20 to 24 ; Coarse Greensand, 15 ; fine grey and buff sands, absut 120; sandy marlstone, I5; grey marl and clay (G.ault), 90.

No. 1629 , vOL. 637
Royal Microscopical Society, Decenber 19, 1900.-Mr. Wm. Carruthers, F.R.S , President, in the chair.-Mr. Barton exhibited some new forms of lanterns which could be used for ordinary projection purposes either with or without the micro. scope. The first was a lantern constructed so as to exclude all light from the room except what passed through the lenses; the manner of using this in connection with a microscope was shown. Another lantern exhibited was larger and more complete, and could be used for all purposes, including enlargements. The excellent definition of this lantern was demonstrated by the exhibition on the screen of photomicrographs of mounted preparations of insects, and of whole insects mounted in balsam. Mr. Barton also exhibited and described several new forms of micro. scope, with detachable circular stage, \&c., and a new form of electric arc lamp for lantern use. A new form of lime-light was also exhibited of great brilliancy, steadiness and silence. Mr. Nelson said he was very much struck with the perfection to which the last-mentioned lamp had been brought, and inquired if the gases had been enriched in any way, and how the light was produced with such complete absence of noise. MIr. Barton said nothing was used but the two gases, and the effect was produced by causing them to impinge upon each other previous to their entrance to the mixing chamber, and by the construction of the chamber itself.

\section{MANCHESTER.}

Literary and Philosophical Society, January 8.-Prof. Horace Lamb, F. R.S., President, in the chair. $-\Lambda$ discussion was introduced by $\mathrm{Mr}$. W. II. Johnson upon the method of navigation employed by the Norsemen on their voyages between Northern Europe and Greenland and Iceland before the mariner's compass was known. Mr. W. E. Hoyle communicated a note on D'Orbigny's figure of Ony'choteuthis dussumieri, in which he pointed out the resemblance which it bore to a species of Loligo in the Hamburg Museum. The skin of this specimen was partly covered by convex tubercles, giving it a shagreen-like appearance, which was due to its having undergone partial maceration in the stomach of some cetacean. It was further shown that this appearance might perhaps explain the true nature of a cephalopod described by Prof. Joubin, which he stated to be covered with scales resembling those of a ganoid fish. Dr. Lïnnberg had found a similar appearance in a specimen of Onychoteuthis from Magellan's Straits, which on investigation proved not to be due to scales at all, but to a swelling of subcutaneous papill:e in consequence of the maceration to which the animal had been subjected. It seemed, therefore, a reasonable hypothesis that all these scalelike appearances were due to a similar cause.

\section{Enix́mRgh}

Mathematical Society, January 11.-Mr. Geo. Duthie, Vice-President, in the chair. - Prof. Allardice read a paper on the nine-point conic, and notes were given by Prof. Steggall, Mr. D. B. Mair and Prof. Jack.

\section{PARIS,}

Academy of Sciences, January 7.-M. Fouqué in the chair. - M. Bouquet de la Grye was elected Vice-President for the year rgor.-M. Maurice Lévy, the retiring President, announced the changes in the members and correspondents for the past year. - The President announced the death of Dr. Potain, member in the section of Medicine and Surgery.-On the integrals of total differentials of the third species in the theory of algebraic functions of two variables, by M. Emile Picard.-Observations of the comet $1900 c$ (Giacobini), made at the Observatory of Algiers, by MIM. Rambaud and Sy. The observations, which were made with the $31 \cdot 8 \mathrm{~cm}$. equatorial on the nights of December 26 and 27,1900 , show that the comet is a nebulosity of $I^{\prime}$ to $z^{\prime}$ dianeter with a feeble central nucleus comparable in intensity with a star of the $13^{\text {th }}$ magnitude.-Observations of the comet I900c (Giacobini) made with the equatorial of the Observatory of Besancon, by M. P. Chofardet. The observations were made on December 25, 1900 , and show the comet as a rounded nebula without a tail, with a central stellar nucleus of about the 12 th magnitude.-On convex closed surfaces, by M. H. Minkow'ski. - On the theorem of active forces, by M. H. Duport.--On linear equations with indeterminate points, by $M$. Ludwig Schlesinger.-On the theory of the equations of mathematical physics, by M. S. Zaremba.-On the absolute value of the magnetic elements on 
January I, by M. Th. Moureaux. The absolute values of the magnetic elements is given for four stations, Parc Saint-Maur, Nice, Pernignan and Val Joyeux. The removal of the magnetic instruments to this last station from Parc Saint-Maur was rendered necessary during the year by the increasing disturbances caused by the development of the electrical tramway system of Paris.-On a new phosphide of tungsten, by M. Ed. Defacqz. All attempts to prepare the tungsten phosphide, WP, at the temperature of the electric furnace were unsuccessful, owing to the fact that at the temperature of boiling copper phosphide the tungsten phosphide is dissociated. By working at the highest attainable temperature of a wind furnace, however, in presence of a large excess of copper phosphide, a well crystallised phosphide was obtained having the composition WP. This forms prismatic crystals of a grey metallic lustre, density $8 \% 5$, not attacked by air at the ordinary temperature, but converted into tungstic acid at a red heat.-On some properties of sodium peroxide, by $\mathrm{M}$. (ieorge $\mathrm{F}$. Jaubert. Sodium peroxide is commonly described as a white substance which deliquesces slowly when exposed to the air. The author now finds that the colour of this substance when prepared in a perfectly pure state is yellow, and further that it does not liquefy when exposed to the air. - Composition of the hydride and nitride of thorium, by MM. C. Matignon and M. Delépine. At a dull red heat metallic thorium burns in a current of hydrogen forming the hydride ThII. With nitrogen, if the metal be heated somewhat more strongly, the nitride $\mathrm{Th}_{3} \mathrm{~N}_{4}$ is formed, which is rapidly decomposed by hot water with the formation of thoria and ammonia.-Some new reactions of the organo-metallic derivatives, by M. E. E. Blaise. A description of a new general method for the preparation of ketones and ketonic acids. The reagent used is the alkyl magnesium iodide obtained by the action of magnesium upon an alkyl iodide, and this is allowed to react with either a nitrile or an isocyanic ester. Thus in this way the author has obtained propionoacetic ester from cyanacetic ester, dicthyl ketone from cyanogen, and substituted anilides from phenyl isocyanate.-Action of methyl-acetylacetone and ethyl-acetylacetone on the diazoic chlorides, by M. G. Favrel. The diazo-chlorides react with methyl-or ethyl-acetylacetone with the elimination of a molecule of acetic acid and formation of a hydrazone. This reaction resembles that of the cyanacetic esters containing substituted acid radicles, and also the reaction between the alkyl-acetylacetic esters and diazobenzene chloride. -On the embryology of Taenia serrata, by M. G. Saint-Remy. The author gives reasons for believing that the description given by van Beneden of the young egg, not segmented, is not quite exact, and that this description belongs in reality to a slightly more advanced stage. - On the discovery of an origin of the Swiss Pre-alps, by II. Maurice Lugeon.

\section{DIARY OF SOCIETIES.}

\section{THURSDAY, JANUARY 17.}

Royat. Sugferr, at $4: 30$-Total Eclipse of the Sun, January 22, 1808 . Observations at Viziadrug. Part IV. The Prismatic Cameras: Sir N. Leckyer, K.C.B.. F.R.S.-Wave-length Jeterminations and General Results obtained from a Detailed Examination of Spectra photographed at the Solar Ficlipse of January 22, 1898: J. Evershed.-The ThermoChemistry of the Alloys of Copper and Zinc: T. J. Baker.

Roval. INSTITUTION, at 3.-The Origin of Vertebrate Animals: Dr. Arthur Willey.

Societr of ARTS (Indian Section), at 4.30.-Mctalliferous Mining in India: Dr. John W. Evans.

Lindia: Dr. John W. Evans. LiNeA. SOCIETY, at 8. - On the Affinities of Acluropus niclanoleucus,
Prof. E. Ray Lankester, F.R.S., with a Descrintion of the Skull and Prof. E. Ray Lankester, F. R.S., with a Description of the Skull and
some of the limb-bones: R. Lydekker, F.R.S.-On the Natural History some of the Limb-bones: R. Lydekker, F.R.S. - On the Natural History
and Artificial Cultivation of the Pearl Oystcr: Dr. H. I.yster Jameson. and Artificial Cultivation of the Pearl Oyster: Dr. H. I yster Jameson.
Crromicat Socin'sy, at 8. - I he Preparation of Esters from otber Esters CMralical SOCIE'Ty, at 8. - I he Preparation of Esters from otber Esters of the same Acid: T. T. Patterson and Cyril Dickinson.-Tecomin: a Colouring Miatter derived from Biynonia recoma: T. H. Lee.-A New Mcthod for the Measurcment of lonic Velocities in Aqueous Solution B. D. Stcele.- Metal-Ammonia Compounds in Aqueous Solution. II.
The A bsorptive Powers of Dilute Solutions of Salts of the Alkali Metals H. M. Dawion and J. McCrae.

\section{FRIDAY, JANUARY I 8}

Roval Instrtetion, at 9.- Gases at the Beginning and End of the Century: Prof. J. I)ewar, F.R.S.

INSTITUlon of Mrichasical. ENGinkeks, at 8. -Annual General Meet. ing.-P'ossible discussion upon Mr. H. A. Humphrey's paper on Power Gas and Large Gas-Engines for Central Stations.

\footnotetext{
MONDAY, JANUARY $2 \mathrm{I}$.
}

VICTORIA Institute, at $4 \cdot 3^{\circ},-$ kvolution: Rev. G. F. Whidborne. No. I 629 , voL. 63]

\section{TUESDAY, JANUAKY 22}

Royal Instrutution, at 3.-Practical Mechanics: Prof. J. A. Ewing, F.R.S.

Anthropolocical Institute, at 8.30.-On Malay Metal-working (illustrated by Lantern Slides and Experiments): W. Rosenhain.-Slides illustrative of the damage to Stonehenge will also be shown.

Instirution of Civil ENginferse, at 8.-The Present Condition and Prospects of the Panana Canal Works: J. T. Ford.

MINERALOGICAI SOCIETY, at 8.-Note on an Occurrence of Mirabilite: Dr. Trechmann. - On a Question relative to Fixtinction-Angles in Rock. Slices: Mr. Harker-On the Arrangement of the Chemical Atoms in Calc Spar and in some other Crystals: Mr. Barlow.

Roval PHOTOGRAPHIC Socigty, at 8.- Imitative versus Creative (a Comparison): W. Edwin Tindall.

\section{WEDNESDAY, JANUARY 23.}

Geological Socifty, at 8. -The Glacial Geology of Victoria, Australia Prof. J. W. Gregory.-1'the Origin of the Dunmail Raise(Lake District) : R. D. Oldham.

\section{THURSDAY, JANLARY 24.}

Royal Socifiry, at 4.30.-Probable papers: The Boiling Point of Liquid Hydrogen, determined by Hydrogen and Helium $G$ as Thermometers Prof. J. Dewar, F.R.S. - Investigations on the Abnormal Outgrowths or Intumescences on Hitiscus. vitifolizs, Linn.: a Study in Experimental Plant Pathology: Miss Elizabeth Dale.-On the Proteid Reaction of Adamkiewic\%, with Contributions to the Chemistry of Glyoxylic Acid : F. Gowland Hopkins and S. IV. Cole.

Roval Institutios, at 3.--Origin of Vertebrate Animals: Dr. Arthur Willey.

Institution of Eiretrical Engineers, at 8.- - djourned Discussion: Capacity in Alternate Current Working: W. M. Mordey.

\section{FRIDAY, JANLARY 25}

PHYSICAI. Society, at 5.-The New Physical I aboratories of the Royal College of Science : Prof. A. W. Rüicker, Sec. R.S.-Note on an Absolute Method for determining the Hygrometric State of the Atmosphere : E. B. H. Wade.-Exhibition of an Experiment on the Migration of the lons: S. W. J. Smith.

Ixstitution of Civil Engineers, at 8.-Sewage Treatment: C. Johnston.

$$
\text { SATURDAY, JANIIARY } 26 .
$$

Royal Institution, at 3.-The Government and People of China: Prof. R. K. Douglas.!

\section{CONTENTS.}

Modern Thermodynamics ........ 269

An Authoritative 'Text-Book of Physiology . . . 270 The Royal Observatory, Greenwich. By H. H. T. 271 The Management of Roads ....... . 272 Our Book Shelf :-

Turner: "Knowledge, Belief, and Certitude."H. W. B. .

Renard and Stüber : "Notions de Minéralıgie" . . 273

Curtis: "The Essentials of P'ractical Bacteriology: an Elementary Laboratory Book for Students and Practitioners"

Hovenden: "What is Heat? and What is Electricity?" ............. 274

Letters to the Editor:-

On a Proof of Traction-Elasticity of Liquids. - Prof. G. van der Mensbrugghe - Karl Pearson, F.R.S.

Education in Scienc- -James Sutherland • . 274

Abbe's Optical Theorems. -Prof. J. D. Everett, F.R.S. . . . . . . 2 276

Fireball in Sunshine.-W. F. Denning $\therefore 276$

Air and Disease:-Harold Picton . . . . 276

Recent Advances in the Geology of Igneous Rocks 276

The Disappearance of Images on Photographic

Plates. By Dr. William J. S. Lockyer. . . 278

Vibration of Gun-barrels. (Illustrated.) By F. J.-S. 279 The Royal Indian Engineering College. . . . . 280 Notes . . . . . . . . . . . 280

Our Astronomical Column :-

Origin of Terrestrial Magnetism . . . . . . 286

Opposition of Mars in $1888 \ldots 286$

Double Star Measures ... . . . . . . . 286

Scientific Developments of Biology and Medicine 286 The Distribution of Vertebrate Animals in India, Ceylon, and Burma. By Dr. W. T. Blanford, F.R.S. Teachers in Conference ${ }^{\circ y}{ }^{\circ}{ } T$. Simmons . . . . . . . . . 289 University and Educational Intelligence . . . . . . . 289 Scientific Serials . . . . . . . . . 290 Societies and Academies. . . . . . . . . 29I Diary of Societies ................... 292 